\title{
D-dimer levels as a prognostic factor for determining oncological outcomes in musculoskeletal sarcoma
}

\author{
Takeshi Morii*, Kazuo Mochizuki, Takashi Tajima, Shoichi Ichimura and Kazuhiko Satomi
}

\begin{abstract}
Background: Plasma d-dimer levels have been associated with the status of tumor progression or oncological outcomes in cancer. Although there are many evidences suggesting the involvement of procoagulant trend in musculoskeletal sarcoma, no clinical data on d-dimer levels and oncological outcome of musculoskeletal sarcoma has been reported.

Methods: In this study, we included a total of 85 patients who were diagnosed with musculoskeletal sarcoma and treated at our institute. Plasma d-dimer levels were determined before performing any clinical intervention, including open biopsy, chemotherapy, radiotherapy or tumor resection. We evaluated the effect of d-dimer levels and other clinicopathological factors on oncological outcomes of patients.

Results: Upregulation of plasma d-dimer levels proved to be an independent risk factor for metastasis and lethal outcome of patients with musculoskeletal sarcoma.

Conclusions: Upregulation of plasma d-dimer levels were indicated poor oncological outcome in metastasis and total survival rate of musculoskeletal sarcoma patients. Hence d-dimer levels may be a helpful marker for evaluating the tumor progression status and prognosis of musculoskeletal sarcoma.
\end{abstract}

\section{Background}

Deterioration in the hemostatic status is one of the significant physiological changes induced by malignant condition. The close relationship between cancer and thrombosis has been clinically well established. Indeed, the risk of venous thromboembolism is higher in cancer patients than in non-cancer patients [1].

Various kinds of procoagulant factors such as malignant condition itself, chemotherapy, long rest period, pathological fracture, orthopedic surgery, and reconstruction by prosthesis or plastic surgery, have been associated with musculoskeletal sarcoma. Indeed, the incidence of venous thromboembolism caused by systemic activation of clotting-fibrinolytic system in musculoskeletal sarcoma patients is considerably high [2-5].

Direct or collateral evidences suggested the involvement of procoagulant molecular mechanisms in

\footnotetext{
* Correspondence: t-morii@gb3.so-net.ne.jp

Department of Orthopaedic Surgery, Kyorin University, School of Medicine, 6-20-2 Shinkawa, Mitaka Tokyo 181-8611, Japan
}

musculoskeletal sarcoma. Some examples are as follows. (1) Tissue factor (TF) is a key factor in thrombin generation/fibrin formation and regulates procoagulant activity in many cancer tissues $[1,6,7]$. This molecule has been reported to be upregulated in a human osteosarcoma cell line [8]. (2) Fibrinolytic molecules that regulate fibrinolytic pathway in tumor tissue include urokinase type plasminogen activator, urokinase type plasminogen activator receptor, and plasminogen activator inhibitors [1]. The expression of these fibrinolytic molecules was reported to be changed in musculoskeletal malignancy $[9,10]$. (3) Tumor cells secrete various proinflammatory or proangiogenic cytokines such as tumor necrosis factor-alpha, interleukin-1 beta or vascular endothelial growth factor (VEGF), which may affect the anticoagulant system [1]. There is a close relation in the expression and function between VEGF and TF $[11,12]$. Upregulation of VEGF has been widely reported in musculoskeletal malignancy [13].

D-dimer, a degradation product of cross-linked fibrin blood clots, is an indicator of fibrin concentration.
C Biomed Central

() 2011 Morii et al; licensee BioMed Central Ltd. This is an Open Access article distributed under the terms of the Creative Commons Attribution License (http://creativecommons.org/licenses/by/2.0), which permits unrestricted use, distribution, and reproduction in any medium, provided the original work is properly cited. 
Upregulation of plasma d-dimer levels has been reported in several procoagulant pathophysiological conditions, including cancer. Recent studies revealed that plasma ddimer levels could be used to determine tumor stage/ grade [2,14-17], disease progression/response to treatment $[18,19]$, or oncological outcome $[17,20,21]$. However, the relevance of $\mathrm{d}$-dimer levels as a prognostic factor of musculoskeletal sarcoma has not yet been established thus far. On the basis of the abovementioned data, we hypothesized that plasma d-dimer levels in musculoskeletal sarcoma patients were indicators of tumor progression and oncological outcome, and we analyzed the effect of d-dimer levels on metastasis and lethal outcome in order to establish the clinical significance of d-dimer levels as a prognostic marker.

\section{Methods}

We designed a retrospective uncontrolled study based on data obtained from medical records. The inclusion criteria for this study were as follows: (1) musculoskeletal sarcoma diagnosed and treated at our institute between 2006 and 2010; (2) patients who had undergone standard oncological resection [22]; (3) adequate clinical information in the records; and (4) at least 12 months follow-up, except in the case of death before that time. Patients were excluded if the presence of any of the following was identified at the time of presentation: (1) evident metastases; (2) pathological fracture; (3) preexisting hypercoagulopathy; (4) recent anticoagulant therapy including prophylaxis of thromboembolic complications; (5) recent trauma; (6) inflammatory diseases; and (7) other major surgery recently performed. Finally, 85 patients who met these criteria were included in this study. Clinicopathological and demographic variables of this cohort are summarized in Table 1 .

Adjuvant and neoadjuvant systemic chemotherapy were performed in less than 65 years old patients with high grade sarcoma. The treatment regimens were selected based on the histological findings of the patients [23-25]. Radiotherapy was performed postoperatively only for 6 patients in whom postoperative pathological evaluation suggested microscopic residual tumors. Histological grade and surgical margin was determined as previously described [22]. Tumor relapse was detected by physical examination of the tumor site and regional lymph node and by computed tomography

Table 1 Characteristics of the patients

\begin{tabular}{|c|c|c|c|c|}
\hline \multirow[t]{2}{*}{ Age (year) } & & Mean & 55.7 & \\
\hline & & Range & 9-95 & \\
\hline \multirow[t]{2}{*}{ Sex } & & Male & 38 & $(44.7 \%)$ \\
\hline & & Female & 47 & $(55.3 \%)$ \\
\hline \multirow[t]{3}{*}{ Location } & & Upper extremity & 14 & $(16.5 \%)$ \\
\hline & & Lower extremity & 47 & $(55.3 \%)$ \\
\hline & & Trunk & 24 & $(28.2 \%)$ \\
\hline \multirow[t]{2}{*}{ Extension } & & Intracompartmental & 36 & $(42.4 \%)$ \\
\hline & & Extracompartmental & 49 & $(57.6 \%)$ \\
\hline \multirow[t]{2}{*}{ Tumor size (mm) } & & Mean & 87.0 & \\
\hline & & Range & 20-308 & \\
\hline \multirow[t]{10}{*}{ Diagnosis } & Bone & & 19 & \\
\hline & & Osteosarcoma & 10 & $(11.8 \%)$ \\
\hline & & Chondrosarcoma & 8 & $(9.4 \%)$ \\
\hline & & Others & 1 & $(1.2 \%)$ \\
\hline & Soft tissue & & 67 & \\
\hline & & Liposarcoma & 23 & $(27.1 \%)$ \\
\hline & & Undifferentiated pleomorphic sarcoma & 14 & $(16.5 \%)$ \\
\hline & & Leiomyosarcoma & 7 & $(8.2 \%)$ \\
\hline & & Malignant peripheral nerve sheath tumor & 5 & $(5.9 \%)$ \\
\hline & & Others & 17 & $(20.0 \%)$ \\
\hline \multirow[t]{2}{*}{ Grade } & & High & 48 & $(56.5 \%)$ \\
\hline & & Low & 37 & $(43.5 \%)$ \\
\hline \multirow[t]{2}{*}{ Surgical margin } & & Adequate & 74 & $(87.1 \%)$ \\
\hline & & Inadequate & 11 & $(12.9 \%)$ \\
\hline \multirow[t]{2}{*}{ Follow up period (months) } & & Mean & 23.0 & \\
\hline & & Range & $6-50$ & \\
\hline
\end{tabular}


scan of lungs by the standard procedure. Mean follow up period was 23.0 (6-50) months.

Plasma d-dimer levels were assessed before performing any kind of intervention for tumor, including chemotherapy, radiotherapy, open biopsy, or tumor resection. For the measurement of d-dimer levels, a latex agglutination assay (STA Liatest ${ }^{\mathbb{B}}$ D-Di (Roche Diagnostics AG, Rotkreuz, Switzerland), which was performed on the STA- $\mathrm{R}^{\circledR}$ coagulation analyzer) was peformed $[2,3]$. On the basis of the sensitivity of this assay, levels $<0.20 \mu \mathrm{g} / \mathrm{ml}$ were considered as $0.20 \mu \mathrm{g} / \mathrm{ml}$.

The endpoints of this study were local recurrence, metastasis, and total survival. The independent risk factors in the present study were patient' age, sex, anatomic site, tumor origin (bone vs soft tissue), histological grade, extracompartment extension, tumor size, surgical margin, and d-dimer levels on referral.

Statistical analysis was performed using the receiver operating characteristic (ROC) curve analysis, KaplanMeier methods, log-rank tests, and Cox proportional hazards model with JMP (version 7; SAS institute Inc., North Carolina, USA). The differences were considered significant when $\mathrm{p}<0.05$. For multivariate analysis, covariates with a $\mathrm{p}$ value of less than 0.05 were retained in the final model. The study was approved by the institutional review board of the authors institution.

\section{Results}

The d-dimer levels ranged from 0.2 to $8.3 \mu \mathrm{g} / \mathrm{ml}$ (mean, $0.84 \mu \mathrm{g} / \mathrm{ml}$; median, $0.42 \mu \mathrm{g} / \mathrm{ml}$ ). In order to determine the cut off value of d-dimer levels in this analysis, we performed ROC curve analysis (Figure 1). The areas under the curve (AUC) were 0.437 for local recurrence, 0.712 for metastasis and 0.749 for total survival, suggesting that there was no evident difference in the levels of $d-$ dimer in patients with and without local recurrences; hence, local recurrence was deleted from the endpoints of this study. The optimal cut off value of d-dimer was determined at the point on ROC curve at which (sensitivity+specificity-1) was maximized (Youden index). For metastasis, optimal cut off value of d-dimer was $0.41 \mu \mathrm{g} /$ $\mathrm{ml}$ with which sensitivity and specificity were 0.83 and 0.57 , respectively. In a similar way for total survival, optimal cut off value of $\mathrm{d}$-dimer was $0.80 \mu \mathrm{g} / \mathrm{ml}$ with which sensitivity and specificity were 0.80 and 0.75 , respectively.

Next, the effect of independent variables, including ddimer levels, on the 2 endpoints, namely, metastasis and total survival, was analyzed by using survival analysis model. The result of univariate analysis suggested that elevated $\mathrm{d}$-dimer levels $(\mathrm{p}=0.002)$ (Figure $2 \mathrm{~A})$ and histological grade $(\mathrm{p}=0.009)$ were the significant risk factors for metastases (Table 2); further, elevated $d$-dimer levels $(\mathrm{p}=0.0004)$ (Figure $2 \mathrm{~B})$, histological grade $(\mathrm{p}=$ 0.03 ), and extracompartmental extension of the tumor $(\mathrm{p}=0.04)$ were the significant risk factors for lethal outcome (Table 3). Multivariate analysis results suggested that both elevated $\mathrm{d}$-dimer levels $(\mathrm{p}=0.003)$ and histological grade $(\mathrm{p}=0.01)$ were the independent risk factors for metastases, and elevated d-dimer levels ( $\mathrm{p}=$ 0.004 ) and extracompartmental extension of the tumor $(\mathrm{p}=0.04)$ were the independent risk factors for lethal outcome.

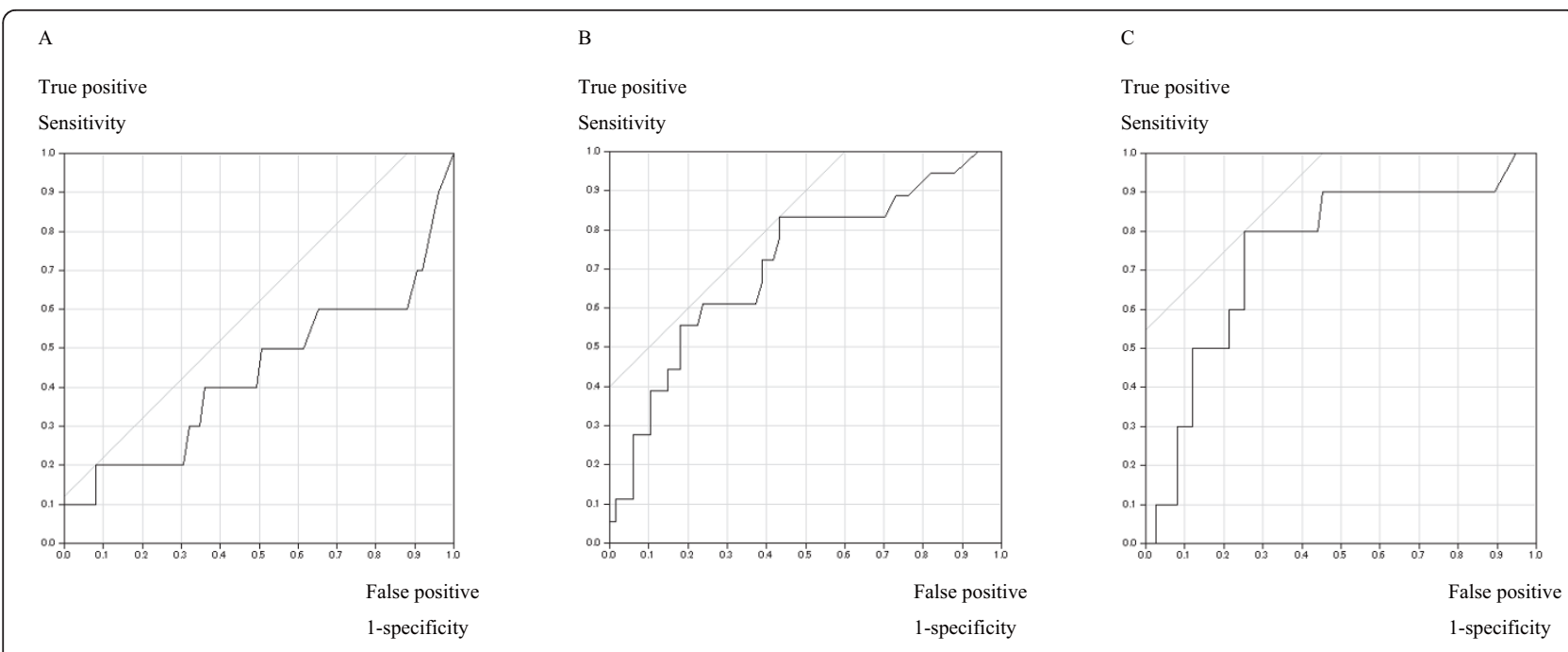

Figure 1 The receiver operating characteristic curve analysis. The receiver operating characteristic (ROC) curve analysis was performed in order to determine the cut off value of d-dimer levels. A. Local recurrence. B. Metastasis. C. Tumor specific death. The optimal cut off value of ddimer was determined at the point on ROC curve at which (sensitivity+specificity-1) was maximized (Youden index). For metastasis, optimal cut off value of d-dimer was $0.41 \mathrm{\mu g} / \mathrm{ml}$ with which sensitivity and specificity were 0.83 and 0.57 , respectively. In a similar way for total survival, optimal cut off value of d-dimer was $0.80 \mu \mathrm{g} / \mathrm{ml}$ with which sensitivity and specificity were 0.80 and 0.75 , respectively. 


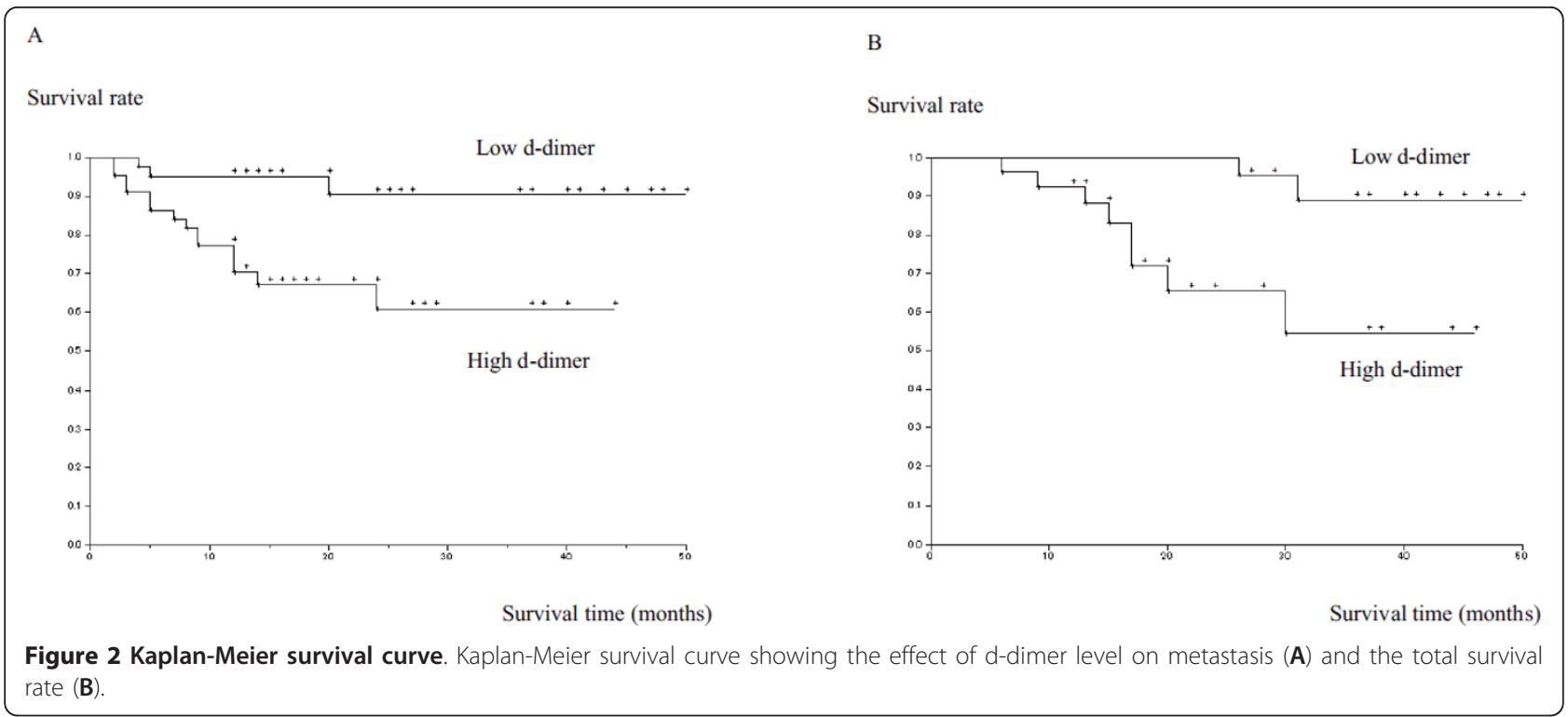

\section{Discussion}

Musculoskeletal sarcoma is a group of rare heterogeneous tumors of the mesenchymal lineage. Innovation in treatment modality, including theory in determining safety margin, limb salvage procedure and systemic chemotherapy have improved oncological outcomes of musculoskeletal sarcoma over the past 3 decades [22]. Accumulated clinical data suggested that several clinicopathological factors, including histological grade, tumor size, surgical margin, tumor extension, and age are prognostic factors of oncological outcome [22,26,27]. In order to evaluate the biological properties of musculoskeletal sarcoma, additional markers are being intensively investigated.

D-dimer is a degradation product of cross-linked fibrin blood clots and indicates fibrin concentration. We have previously shown that plasma d-dimer levels were closely related to the histological grade of musculoskeletal tumor

Table 2 Risks for metastasis

\begin{tabular}{|c|c|c|c|c|c|c|c|}
\hline \multirow[t]{2}{*}{ Variables } & \multirow[t]{2}{*}{ Subclass } & \multirow[t]{2}{*}{ Event } & \multirow[t]{2}{*}{ Cases } & \multirow{2}{*}{$\frac{\text { Univariate analysis }}{\mathrm{p}}$} & \multicolumn{3}{|c|}{ Multivariate analysis } \\
\hline & & & & & $p$ & Hazard ratio & 95\% Confidence interval \\
\hline \multirow[t]{2}{*}{ Age } & $\geqq 56$ years & 8 & 42 & 0.54 & & & \\
\hline & $<56$ years & 10 & 43 & & & & \\
\hline \multirow[t]{2}{*}{ Sex } & Male & 12 & 47 & 0.24 & & & \\
\hline & Female & 6 & 38 & & & & \\
\hline \multirow[t]{3}{*}{ Site } & Upper extremity & 2 & 14 & 0.72 & & & \\
\hline & Lower extremity & 11 & 47 & & & & \\
\hline & Trunk & 5 & 24 & & & & \\
\hline \multirow[t]{2}{*}{ Origin } & Bone & 6 & 19 & 0.20 & & & \\
\hline & Soft tissue & 12 & 66 & & & & \\
\hline \multirow[t]{2}{*}{ Histological grade } & Low & 3 & 37 & 0.009 & 0.01 & 3.9 & $1.2-16.9$ \\
\hline & High & 15 & 48 & & & & \\
\hline \multirow[t]{2}{*}{ Extracompartment extension } & No & 5 & 36 & 0.15 & & & \\
\hline & Yes & 13 & 49 & & & & \\
\hline \multirow[t]{2}{*}{ Tumor size } & $\geqq 50 \mathrm{~mm}$ & 13 & 57 & 0.58 & & & \\
\hline & $<50 \mathrm{~mm}$ & 5 & 28 & & & & \\
\hline \multirow[t]{2}{*}{ Surgical margin } & Adequate & 15 & 74 & 0.56 & & & \\
\hline & Inadequate & 3 & 11 & & & & \\
\hline \multirow[t]{2}{*}{ D-dimer levels } & $\geqq 0.41 \mu \mathrm{g} / \mathrm{ml}$ & 15 & 44 & 0.002 & 0.003 & 5.0 & $1.6-21.7$ \\
\hline & $<0.41 \mu \mathrm{g} / \mathrm{ml}$ & 3 & 41 & & & & \\
\hline
\end{tabular}


Table 3 Risks for lethal outcome

\begin{tabular}{|c|c|c|c|c|c|c|c|}
\hline \multirow[t]{2}{*}{ Variables } & \multirow[t]{2}{*}{ Subclass } & \multirow[t]{2}{*}{ Event } & \multirow[t]{2}{*}{ Cases } & \multirow{2}{*}{$\frac{\text { Univariate analysis }}{\mathrm{p}}$} & \multicolumn{3}{|c|}{ Multivariate analysis } \\
\hline & & & & & $p$ & Hazard ratio & 95\% Confidence interval \\
\hline \multirow[t]{2}{*}{ Age } & $\geqq 56$ years & 4 & 42 & 0.42 & & & \\
\hline & $<56$ years & 6 & 43 & & & & \\
\hline \multirow[t]{2}{*}{ Sex } & Male & 7 & 47 & 0.34 & & & \\
\hline & Female & 3 & 38 & & & & \\
\hline \multirow[t]{3}{*}{ Site } & Upper extremity & 1 & 14 & 0.54 & & & \\
\hline & Lower extremity & 6 & 47 & & & & \\
\hline & Trunk & 3 & 24 & & & & \\
\hline \multirow[t]{2}{*}{ Origin } & Bone & 4 & 19 & 0.14 & & & \\
\hline & Soft tissue & 6 & 66 & & & & \\
\hline \multirow[t]{2}{*}{ Histological grade } & Low & 1 & 37 & 0.03 & 0.01 & 3.9 & $1.2-16.9$ \\
\hline & High & 9 & 48 & & & & \\
\hline \multirow[t]{2}{*}{ Extracompartment extension } & No & 1 & 36 & 0.04 & 0.04 & 5.9 & $1.1-110$ \\
\hline & Yes & 9 & 49 & & & & \\
\hline \multirow[t]{2}{*}{ Tumor size } & $\geqq 50 \mathrm{~mm}$ & 8 & 57 & 0.29 & & & \\
\hline & $<50 \mathrm{~mm}$ & 2 & 28 & & & & \\
\hline \multirow[t]{2}{*}{ Surgical margin } & Adequate & 7 & 74 & 0.12 & & & \\
\hline & Inadequate & 3 & 11 & & & & \\
\hline \multirow[t]{2}{*}{ D-dimer levels } & $\geqq 0.8 \mu \mathrm{g} / \mathrm{ml}$ & 8 & 44 & 0.0004 & 0.004 & 7.3 & $1.8-49$ \\
\hline & $<0.8 \mu \mathrm{g} / \mathrm{ml}$ & 2 & 41 & & & & \\
\hline
\end{tabular}

[2]. However to date, there has been no report indicating the prognostic relevance of plasma d-dimer levels in musculoskeletal sarcoma. This is the first report showing a close relation between d-dimer levels and oncological outcomes in musculoskeletal sarcoma. In contrast to the result of our previous study, multivariate analysis in this study revealed that $\mathrm{d}$-dimer levels and tumor grade were independent factors. However we were not able to precisely determine the mechanism underlying this result. We believe that $\mathrm{d}$-dimer levels might represent the state of disease progression itself rather than tumor properties represented by genetic changes or morphologic findings.

Musculoskeletal malignancy is characterized by heterogeneity in tumor site and patients age, which may be independent from its biological properties that are regulated by genetic change. Our previous data [2] and analysis of the present cohort (data not shown) suggested that d-dimer levels were significantly upregulated in the elder patient group or downregulated in upper extremity cases. If d-dimer level was significant prognostic factor and the abovementioned close relations between the factors were true, patient age and tumor site might indeed be the prognostic factors in this cohort. Hence, these factors were entered into the independent variables in the present model, which confirmed that these factors had little effect on oncological outcome than the ddimer levels.

In this study, chemotherapy was indicated strictly on the basis of grade/histological subtype of the tumor and patient age. The results of preliminary statistical analysis suggested a strong association between tumor grade and indication of adjuvant chemotherapy $(\mathrm{p}=0.001$, Fisher's exact test) and between age and indication of adjuvant chemotherapy ( $\mathrm{p}=0.0002$, Mann-Whitney $U$ test), suggesting that the application of chemotherapy might serve as a confounding bias. Thus, we did not include application of adjuvant chemotherapy as independent risk factor in survival analysis. In addition, limited number of patients received radiotherapy, and thus, indication of radiotherapy was not considered as risk factor.

The merits of the application of d-dimer levels for predicting oncological outcome in clinical practice was previously shown [17] as being not time and cost efficient, requirement of only small plasma aliquots, and less invasive technique. Thus, we proposed the usage of this modality in evaluation of musculoskeletal sarcoma patients. The limitations of this study are considerably small sample size and candidate bias caused by procoagulant factors, for example, smoking or obesity, which were not evaluated in this study. In addition, it is necessary to validate the cut off value of d-dimer. Thus, accumulation of data from prospective study with a large sample might be needed in the future.

\section{Conclusions}

Upregulation of plasma d-dimer levels indicated poor oncological outcome in metastasis and total survival rate of musculoskeletal sarcoma patients. D-dimer levels may 
be a helpful marker for evaluating the tumor progression status and prognosis of musculoskeletal sarcoma.

\section{Fundings}

This study was supported in part by a Grant-in-Aid for Scientific Research (\#20102031) from the Ministry of Health, Labor and Welfare of Japan.

\section{Authors' contributions}

TM collected the data, performed the statistical analysis and drafted the manuscript. KM collected the data and helped to draft the manuscript. Tा collected the data. SS and KS helped to draft the manuscript. All authors have read and approved the final manuscript.

\section{Competing interests}

The authors declare that they have no competing interests.

Received: 9 April 2011 Accepted: 1 November 2011

Published: 1 November 2011

\section{References}

1. Caine GJ, Stonelake PS, Lip GY, Kehoe ST: The hypercoagulable state of malignancy: pathogenesis and current debate. Neoplasia 2002, 4:465-473.

2. Morii T, Mochizuki K, Kotera M, Imakiire N, Moriwaki T, Satomi K Perioperative $\mathrm{d}$-dimer levels in patients with musculoskeletal tumors. Open Orthop J 2008, 2:130-132.

3. Morii T, Mochizuki K, Tajima T, Aoyagi T, Satomi K: Venous thromboembolism in the management of patients with musculoskeletal tumor. J Orthop Sci 2010, 15:810-815.

4. Nathan SS, Simmons KA, Lin PP, Hann LE, Morris CD, Athanasian EA, Boland PJ, Healey JH: Proximal deep vein thrombosis after hip replacement for oncologic indications. J Bone Joint Surg Am 2006, 88:1066-1070

5. Mitchell SY, Lingard EA, Kesteven P, McCaskie AW, Gerrand CH: Venous thromboembolism in patients with primary bone or soft-tissue sarcomas. J Bone Joint Surg Am 2007, 89:2433-2439.

6. Seto S, Onodera H, Kaido T, Yoshikawa A, Ishigami S, Arii S, Imamura M: Tissue factor expression in human colorectal carcinoma: correlation with hepatic metastasis and impact on prognosis. Cancer 2000, 88:295-301.

7. Zhang Y, Deng $Y$, Luther T, Muller M, Ziegler R, Waldherr R, Stern DM, Nawroth PP: Tissue factor controls the balance of angiogenic and antiangiogenic properties of tumor cells in mice. J Clin Invest 1994, 94:1320-1327.

8. Daubie V, De Decker R, Nicaise C, Pochet R: Osteosarcoma cell-calcium signaling through tissue factor-factor Vlla complex and factor Xa. FEBS Lett 2007, 581:2611-2615

9. Taubert H, Wurl P, Greither T, Kappler M, Bache M, Lautenschlager C, Fussel S, Meye A, Eckert AW, Holzhausen HJ, Magdolen V, Kotzsch M: Codetection of members of the urokinase plasminogen activator system in tumour tissue and serum correlates with a poor prognosis for soft-tissue sarcoma patients. Br J Cancer 2010, 102:731-737.

10. Morii T, Yabe H, Morioka H, Yamada R, Nakagawa T, Toyama Y: Prognostic relevance of urokinase type plasminogen activator, its receptor and inhibitors in chondrosarcoma. Anticancer Res 2000, 20:3031-3036.

11. Nakasaki T, Wada H, Shigemori C, Miki C, Gabazza EC, Nobori T, Nakamura S, Shiku H: Expression of tissue factor and vascular endothelial growth factor is associated with angiogenesis in colorectal cancer. Am J Hematol 2002, 69:247-254.

12. Zucker S, Mirza H, Conner CE, Lorenz AF, Drews MH, Bahou WF, Jesty J: Vascular endothelial growth factor induces tissue factor and matrix metalloproteinase production in endothelial cells: conversion of prothrombin to thrombin results in progelatinase $\mathrm{A}$ activation and cell proliferation. Int J Cancer 1998, 75:780-786.

13. Kilvaer TK, Valkov A, Sorbye S, Smeland E, Bremnes RM, Busund LT, Donnem T: Profiling of VEGFs and VEGFRs as prognostic factors in soft tissue sarcoma: VEGFR-3 is an independent predictor of poor prognosis. PLoS One 2010, 5:e15368.
14. Gadducci A, Baicchi U, Marrai R, Ferdeghini M, Bianchi R, Facchini V: Preoperative evaluation of D-dimer and CA 125 levels in differentiating benign from malignant ovarian masses. Gynecol Oncol 1996, 60:197-202.

15. Oya M, Akiyama Y, Yanagida T, Akao S, Ishikawa H: Plasma D-dimer level in patients with colorectal cancer: its role as a tumor marker. Surg Today 1998, 28:373-378.

16. Kwon HC, Oh SY, Lee S, Kim SH, Han JY, Koh RY, Kim MC, Kim HJ: Plasma levels of prothrombin fragment F1+2, D-dimer and prothrombin time correlate with clinical stage and lymph node metastasis in operable gastric cancer patients. Jpn J Clin Oncol 2008, 38:2-7.

17. Batschauer AP, Figueiredo CP, Bueno EC, Ribeiro MA, Dusse LM, Fernandes AP, Gomes KB, Carvalho MG: D-dimer as a possible prognostic marker of operable hormone receptor-negative breast cancer. Ann Oncol 2010, 21:1267-1272.

18. Khoury JD, Adcock DM, Chan F, Symanowski JT, Tiefenbacher S, Goodman O, Paz L, Ma Y, Ward DC, Vogelzang NJ, Fink LM: Increases in quantitative D-dimer levels correlate with progressive disease better than circulating tumor cell counts in patients with refractory prostate cancer. Am J Clin Pathol 2010, 134:964-969.

19. Antoniou D, Pavlakou G, Stathopoulos GP, Karydis I, Chondrou E, Papageorgiou C, Dariotaki F, Chaimala D, Veslemes M: Predictive value of D-dimer plasma levels in response and progressive disease in patients with lung cancer. Lung Cancer 2006, 53:205-210.

20. Altiay G, Ciftci A, Demir M, Kocak Z, Sut N, Tabakoglu E, Hatipoglu ON Caglar T: High plasma D-dimer level is associated with decreased survival in patients with lung cancer. Clin Oncol (R Coll Radiol) 2007, 19:494-498.

21. Buccheri G, Torchio P, Ferrigno D: Plasma levels of D-dimer in lung carcinoma: clinical and prognostic significance. Cancer 2003, 97:3044-3052.

22. Kawaguchi N, Ahmed AR, Matsumoto S, Manabe J, Matsushita Y: The concept of curative margin in surgery for bone and soft tissue sarcoma. Clin Orthop Relat Res 2004, 419:165-172.

23. Grier HE, Krailo MD, Tarbell NJ, Link MP, Fryer CJ, Pritchard DJ, Gebhardt MC, Dickman PS, Perlman EJ, Meyers PA, Donaldson SS, Moore S, Rausen AR, Vietti TJ, Miser JS: Addition of ifosfamide and etoposide to standard chemotherapy for Ewing's sarcoma and primitive neuroectodermal tumor of bone. N Engl J Med 2003, 348:694-701.

24. Tanaka K, Kawamoto H, Saito I, Yoshimura K, Fukuda H, Iwamoto Y: Preoperative and postoperative chemotherapy with ifosfamide and adriamycin for adult high-grade soft-tissue sarcomas in the extremities: Japan Clinical Oncology Group Study JCOG0304. Jpn J Clin Oncol 2009, 39:271-273.

25. Iwamoto Y, Tanaka K, Isu K, Kawai A, Tatezaki S, Ishii T, Kushida K, Beppu Y, Usui M, Tateishi A, Furuse K, Minamizaki T, Kawaguchi N, Yamawaki S: Multiinstitutional phase II study of neoadjuvant chemotherapy for osteosarcoma (NECO study) in Japan: NECO-93J and NECO-95J. J Orthop Sci 2009, 14:397-404.

26. Parsons HM, Habermann EB, Tuttle TM, Al-Refaie WB: Conditional survival of extremity soft-tissue sarcoma: results beyond the staging system. Cancer 2011, 117:1055-1060.

27. Heck RK Jr, Peabody TD, Simon MA: Staging of primary malignancies of bone. CA Cancer J Clin 2006, 56:366-375.

\section{Pre-publication history}

The pre-publication history for this paper can be accessed here: http://www.biomedcentral.com/1471-2474/12/250/prepub

doi:10.1186/1471-2474-12-250

Cite this article as: Morii et al:: D-dimer levels as a prognostic factor for determining oncological outcomes in musculoskeletal sarcoma. BMC Musculoskeletal Disorders 2011 12:250. 